\title{
ASSEMBLING CLIMATE EXPERTISE: CARBON MARKETS, NEOLIBERALISM AND SCIENCE
}

\section{Samuel Randalls}

\section{INTRODUCTION}

If crisis was productive in the past for the introduction or furthering of neoliberal ideas (Klein 2008), climate change represents a more awkward crisis. Climate change crosses international borders, embraces almost every aspect of production and consumption, and has no simple technological solution. It appears to put environment and development in opposition, augmented with an unequal distribution of impacts, and it is frequently framed as emanating from what Stern (2006) describes as the biggest market failure in history. This is a crisis that, in totality, seems to threaten the contemporary political-economic constitution.

Climate change emerged as part of a series of environmental crises that caused political concern during the 1970s including land degradation, overpopulation, ozone depletion, resource overexploitation, transboundary air and water pollution, and the impacts of technologies such as supersonic transport and nuclear power. The Club of Rome's famous report The Limits to Growth argued that this distinct series of problems would create a dramatic transition from growth to a new equilibrium (Meadows, et al. 1972). This process was more than likely to involve an overshoot and collapse in human population after exceeding the carrying capacity of the planet. Unless warnings were heeded and global governance instituted, the future of life on earth looked bleak. Governments would have to work to protect the environment rather than 
focus on economic growth. As Howe $(2014,89)$ puts it: "The Limits to Growth was nothing if not politically prognosticative" and, of course, contentious.

An environmental movement built on aspirations to change government policy was viewed by advocates of growth as putting economic growth, modernization and even capitalism at risk (Mol and Spaargaren 2000). Climate change was a particularly dangerous issue in this context because it brought together so many ethical, economic and scientific concerns that implied a need for governmental intervention on a global scale. Market advocates were particularly concerned about this potential for the expansion of state interventions in the name of environmental protection and regulation (Oreskes and Conway 2010). They needed to re-assert the indisputable value of the market and ensure that an environmentalist, state-centered response would not be assembled. Environmentalists were cast as watermelons ("green on the outside, red on the inside"), particularly in climate change debates in the United States. A faith in markets or economic progress could simply not be aligned with environmentalist attitudes. Mirowski (2013) has suggested that denial therefore represented the initial response of neoliberal thinkers to "climate crisis". ${ }^{i}$ It was inconceivable to accept that markets could have got it so wrong when it came to climate change; perhaps it simply was not really happening or was not as serious as proponents claimed it was.

Organized denial emanated from a specific set of individuals, industries and think tanks. As Klein (2014) and Oreskes and Conway (2010) have shown, climate science was contested by well-funded sceptics, many of which received funding from neoliberal think tanks and other organizations that have a vested interest in maintaining uncertainty and confusion. As Oreskes and Conway (2010) demonstrate, physicists like Robert Jastrow and Fred Seitz, using tactics developed from contesting links between smoking and cancer, set out about establishing an 
alternative hypothesis for global warming based on changes in sun cycles, while others like Fred Singer exploited scientific uncertainty to make political representation to delay action. Over the last 40 years a number of neoliberal-linked think tanks supported denial including the George C. Marshall Institute, the Heartland Institute, the Cato, the Competitive Enterprise Institute, the Hoover Institution, and the Olin Centre (Oreskes and Conway 2010).

Yet denial by itself was insufficient to frame long-term responses to climate change. Neoliberal think tanks were not so powerful as to overwhelm ever-increasing scientific and environmental alarm. Thus, for Mirowski $(2013,337)$ "The promotion of denialism buys time for the other two [neoliberal] options; the financialization of carbon credits gets all the attention in the medium term, while appeals to geoengineering incubate in the wings as a techno-utopian deus ex machina to swoop down when the other options fail". In other words, denial, carbon markets and geoengineering were three aspects of a neoliberal response to climate change and would be deployed in that order. Such a sweeping argument demands closer attention to how particular solutions are assembled. It would appear far too easy for "neoliberal ideas" to simply roll-out in practice. Rather, I would argue, carbon markets had to be established economically, accepted politically, supported scientifically and made consistent with neoliberal ideals if such markets were to emerge as a medium-term neoliberal fix.

In this chapter, I first briefly outline why it is useful to consider the assembling of carbon markets rather than treat them simply as a roll-out of neoliberalism. I also adopt a working definition of neoliberalism to provide a short-hand for discussing a coherent set of ideas, but such that does not imply a settled singularity of neoliberalism as such. Next I explore the emergence of carbon markets showing how neoliberal thinkers helped construct a policy architecture enabling them to be constructed as solutions to climate change that would not harm 
business. This argument had to be re-asserted several times as carbon markets were re-shaped following various criticisms. I conclude with some provisional claims about the value of assemblage thinking in a case like carbon markets. ${ }^{\text {ii }}$

\section{ASSEMBLING MARKETS UNDER NEOLIBERALISM}

Research in the social studies of finance has shown how the economy in general, and markets in particular, are enacted through an apparatus of equations, computers, standards, legal frameworks, property rights, accountancy systems, and the creation of equivalent commodities to be traded, to name just a few factors (Callon 2009; MacKenzie 2009; Mitchell 2002). Markets are equally said to have an almost other-worldly quality in maintaining ideals of freedom, competition and the magic of the marketplace in which markets know best and reach ideal decisions (Mirowski 2013). Any functions or services (for example pollution, education, or health care) currently outside of market relations are brought inside through the process of marketization. Marketization re-assembles property rights, equations, accountancy and so on, in the creation of a new privately-owned and tradeable commodity.

Marketization is often considered central to neoliberalism and it is certainly the case that if neoliberalism is identified with a "thought collective" of members of (particularly) the Mont Pèlerin Society, who cohere around broadly shared beliefs or aspirations, then many significant claims are made about markets (Mirowski and Plehwe 2009). While the question of the ontology of the market has been an area of dispute between members of the Mont Pèlerin Society (Mirowski 2013), the market is heralded as the natural mode, even if it required active intervention to construct, and a state to enable, protect and enforce. As Mirowski (2013) notes, despite trust in the market as an information processor far beyond the capacities of any information or state, this market had to be constructed rather than simply unfold by itself. This 
conception of markets as constructed is particularly important in the case of environmental pollutants.

Cap-and-trade markets, by definition, require a cap to be set on the total number of credits available in the marketplace for trading. The value of credits is to a significant degree shaped by the number of credits available as has been illustrated in the decline of prices for emissions credits in the early years of the best-developed carbon market, the European Union Emissions Trading Scheme (E.U.E.T.S.) (MacKenzie 2009). Caps, however, cannot be conceived as natural orders that enable a purely optimal market-based outcome to be achieved. The caps in emissions trading are not purely determined by market relations, but rather by the administrative practice of state regulators. MacKenzie $(2009,451)$ highlights this compromise in emissions trading, arguing that suspicion "ranging from right wing distaste for emissions caps to left wing hostility to an extension of market relations" has pervaded their emergence. Carbon markets, therefore, do not reflect a simply unfolding neoliberalism; their production, amidst claims of climate crisis, has shaped their emergence.

Scholars such as Callon (2009) and MacKenzie (2009), inspired by actor-network theory, have drawn attention to the ways carbon markets have enrolled allies and cooled controversies to stabilize their formation. MacKenzie (2009) has demonstrated the importance for trade of creating a uniform measure of a greenhouse gas credit, denominated in Carbon Dioxide Equivalent $\left(\mathrm{CO}_{2} \mathrm{e}\right)$, which stabilizes the different warming potentials of different gases. Equally, the accounting, certification and property rights framing that protect the $\mathrm{CO}_{2} \mathrm{e}$ credit as a genuine, privately-owned and tradeable object has been essential to the stabilization of a carbon market (MacKenzie 2009). By contrast, Lohmann (2009; 2011) suggests that even if carbon markets have to some extent been cooled down, they have been unable to shake off the 
critiques of an inadequate response to climate crisis. Lohmann identifies a number of reasons for this including the failure to clamp down on the trading of high greenhouse gas potential industrial by-products, ${ }^{\text {iii }}$ challenges with verifying emission credits, questions about the viability and veracity of offsets, and the political implications of market trading on local communities especially when it comes to carbon offsets. For Lohmann, this is a debate that should be heated up.

Blok (2011) usefully delineates these contrasting interpretations of the politics of carbon markets. He suggests that Lohmann and MacKenzie provide two politically-divergent interpretations. For Blok (2011), the former entrains economic performativity to fit activist leftist political goals and the latter uses the same principles to argue for the political viability of carbon markets. Or to cast it more transparently: the first entails a critique of neoliberal ideals in advancing climate change solutions while the latter is about finding plausible solutions to climate change, and that might mean marketizing carbon. One route out of the political impasse is to treat carbon markets as an exercise in experimentation (Callon 2009; Blok 2011), but while it makes sense in actor-network terms, this would preclude discussion of neoliberalism or events generated by climate crisis. Assemblage thinking might enable understanding of the stabilization of carbon markets (with actor-network theory), but additionally, as always provisional and responsive to new events or crises through which they are re-shaped.

This rapprochement between actor-network theory and assemblage theory could lead to a productive conversation as Müller and Schurr (2016) suggest. They insist that assemblage scholars could learn much from how actor-network theory empirically substantiates the way things come to be, while both share a concern for events and fluidities. Crises such as climate 
change did not provide obvious or easy interventions to further establish neoliberal ideals. Capand-trade markets had to be assembled as a climate policy solution, and as Larner (2011) points out, crises open up different alternatives that could have been realized (Larner 2011). This is where assemblage thinking is particularly attractive. Assemblage thinking enables the demonstration of the concomitant production of social formations through human and nonhuman actants, and how these formations lead to certain pathways being opened up or foreclosed (Anderson et al. 2012). Neoliberal formations are continually in tension with other ways of acting, yet they have an enduring quality derived from the philosophical coherence and everyday internalization in discourse and practice that leads to their continual strategic reassembling. In other words, a neoliberal formation might be said to endure because it is both "fluid and fixing" or cohering (Anderson, et al. 2012), albeit, as a paradoxical conceptual problem, that to discuss such a singular formation too fixedly might in and of itself undercut the notion of assemblages as continually in emergence.

Mirowski's (2013) own conception of neoliberalism hints at this struggle. There are complex and even paradoxical interventions in the name of advancing neoliberal ideas, but these are not left unchanged by new and emerging crises. Indeed, the oft-quoted Foucault phrase that neoliberalism "should be regarded as a call to vigilance, to activism, to perpetual intervention" (Foucault, cited in Mirowski, 2013, 53) captures this spirit of responding to new events particularly well. The neoliberal think-tanks and institutions (as identified by Plehwe and Walpen 2006) do not simply roll out neoliberal responses; neither is marketization a smooth unfolding process. Rather, as the divergent interpretations of MacKenzie and Lohmann highlight, carbon markets are provisional assemblages that neither remove other possibilities, nor are able to absorb all criticism unchanged. The historical formation of carbon markets helps demonstrate this. 


\section{ASSEMBLING CARBON MARKETS}

As noted in the introduction, there were many possible responses to the environmental crises of the 1970s. Some involved a retreat from modernization; others a plan for deepening marketization and a global economy. While denial was a vocal strategy, economists and policymakers worked to establish alternative solutions that would be economically efficient and maintain faith in the market. Carbon markets came to perform an important role in achieving this ambition.

In the 1960s, the economists Ronald Coase (a member of the Mont Pèlerin Society and winner of the 1991 Nobel Prize in Economic Sciences) and John H. Dales (whose name lends itself to a memorial leadership award from the Environmental Markets Association) formulated theories for the operation of cap-and-trade markets. Coase's Theorem removed the concept of externalities and enabled property rights to be allocated in a way that marketization could become possible for a wide range of previously non-marketized goods (Mirowski 2013). Externalities were an awkward concept, because they suggested an area beyond the market, an excess or outside that remained separate from market relations. Cap-and-trade essentially internalized the environment into market-oriented governance, enabling marketization to take the place of an ethos of state management of public goods. In other words, Coase's argument for the efficient allocation of resources through markets enabled economists to make the environmental crisis safe(r) for the Mont Pèlerin Society thought collective. Coase and Dale's work was taken up in minor experiments in the 1970s and 1980s (MacKenzie 2009). Later economists like Terry Anderson (attendee of Mont Pèlerin Society meetings) and Gary Libecap, who met as Senior Fellows at the Hoover Institution (Anderson and Libecap 2014), drew on Coase's work to continue to make the case for environmental markets through the 
1980s. Within political institutions, Michael Grubb, adviser to the United Nations Environment Program and director of the Royal Institute of International Affairs Program on climate change, helped establish the case for carbon markets. According to Grubb, markets were also being independently confirmed in a Brookings Institution report in 1989 and a supportive study from the New Zealand Ministry of the Environment, which was taken up as evidence for tradeable permits in the first Intergovernmental Panel on Climate Change report (Grubb 1992). The case for marketization was further developed in a United Nations Conference on Trade and Development report Combating Global Warming (United Nations 1992).

Carbon markets, however, were not tried and tested solutions in practice, even as they emerged as the core preferred solution in the United States (US). Their legitimation came from lessons learnt from the historical experience with trading of sulfur dioxide after the 1990 Clean Air Act Amendments helped turn sulfur dioxide into tradeable allowances (MacKenzie 2009). Crucial to both the sulfur dioxide and the carbon markets was the specific expertise of Richard Sandor, an innovator in financial futures markets (Lohmann 2011; see United Nations 1992, for an example of how his expertise was called upon, and in which Sandor writes about his experience of markets). Time magazine labelled Sandor a "Hero of the Environment" for innovation in pollution markets (Cameron 2007), and he received a catalog of environmental awards from mostly business-oriented organizations. Sandor's role in creating new environmental financial products is unparalleled, particularly during the twenty years he spent at the Chicago Board of Trade. Crucially Sandor formed the Chicago Climate Exchange, the key institution introducing cap-and-trade markets into the US, but which also provided a benchmark for cap-and-trade markets globally (Lohmann 2011). In print, Sandor suggested that it was "essential for research to continue as rapidly as possible so that we can implement market solutions to the highly critical environmental problems facing us" (Sandor 1992, 164). The climate crisis thus 
demanded a rapid deployment of markets; the crisis could in this case be turned to an opportunity to further deepen neoliberal interventions.

With regard to international policy, carbon markets were also not a universally accepted solution in the development of the Kyoto Protocol in 1997. The European Union (EU) had regularly set out a preference for carbon taxes; indeed it is interesting that the United Kingdom (UK) House of Lords Select Committee on the European Communities in 1992 concluded that the European Commission's carbon tax proposal was unfeasible and unworkable, siding with the Americans in preferring energy efficiency, an energy levy and tradeable permits instead (HMSO 1992). Advice for this position came from expert witnesses including the aforementioned Michael Grubb, who was asked to provide further evidence on the design and regulations of sulfur dioxide trading in the US. Climate policy commentators have noted that the US was only prepared to commit to signing a climate protocol if carbon markets were adopted as the preferred solution rather than taxes (Damro and Mendez 2003). The EU agreed, but the US failed to sign the Kyoto Protocol anyway leaving the EU in the rather awkward position of winning a protocol that undermined their policy preference. EU negotiators, in consolation, claimed success in experimental innovation for the choice of carbon markets (Damro and Mendez 2003). This kind of political negotiation is awkward to situate within actor-network theory accounts of the emergence of carbon markets, focused as they are on the internal design features and actants that stabilize these markets. It was a political crisis that enabled the re-assembling of markets from an American initiative to a European experiment in practice; and while the resulting markets were established through American experience, EU negotiators preferred to develop their own expertise rather than draw on Sandor (personal communication). ${ }^{\text {iv }}$ The assembling of carbon markets, however, has had to react to a number of political events and games of political prestige. Economic and policy expertise helped 
formulate the case for carbon markets, but it was insufficient to explain the emergence of carbon markets in their particular political formation.

\section{CARBON MARKETS IN PRACTICE: EXPANDING THER REACH}

Once carbon markets were finally initiated in the EU in 2005 (and later in regional greenhouse markets in the US and elsewhere), their performance was carefully watched, measured and frequently critiqued. If theories of marketization appeared strong in principle, they were often challenged by environmentalists and occasionally politicians as being in crisis in the actual experience of market trading. If carbon markets needed to stabilize concerns about state interventionism in markets, they also needed to cool potential criticism from scientists and environmentalists and ensure they delivered on environmental goals too. To understand how carbon markets were legitimated it is important to turn to the carbon science experts that informed market trading. In pollution cap-and-trade markets, the role of scientists is crucial in defining the level of cap and in the case of carbon, specifically, in defining understandings of carbon sources and sinks. A key feature of the E.U.E.T.S. is the ability to trade credits internationally; indeed, the desire for globality was central to the initial justifications for tradeable permits rather than national taxation (United Nations 1992). International credits enabled EU producers to buy credits that were more economically efficiently (i.e. cheaply) produced in poorer countries. These credits would ensure that carbon prices remained lower, giving time to polluting companies to alter operations, while also enabling the EU to claim that it was helping with the development of environmentally-friendly development overseas. Notice again that the market practice was shaped by political goals.

This international market posed an awkward overflow potential, with emissions credits (carbon offsets) produced overseas that might overwhelm prices in the market, limiting the extent of 
pollution reductions at home. These carbon offsets incorporate programs like tree planting, new renewable energy projects and cleaner cooking stoves. Formal offsets in the Clean Development Mechanism or later in afforestation or reforestation projects, require the production of verified carbon credits and this relies on carbon science that would show, for example, how much carbon forests absorbed. This is not straightforward given variations of species type, maturity, climate and vegetation of each forest. These scientific calculations were also embedded in political concerns as the case of Brazil shows (Lahsen 2009). Brazilian politicians and scientists became enmeshed in a debate between European and American political negotiators and scientific teams that had rather different answers to the question of whether the Amazon is a carbon sink or not. The European negotiators politically hoped the Amazon would be a carbon sink as that would force more emissions reductions in the US, although in consequence it left Brazil with the responsibility of protecting the valuable forest carbon resource. If the Americans could show the Amazon was not a carbon sink, it would prop up claims that the US was a large carbon sink itself and therefore might even be net neutral in emission terms despite being the world's largest $\mathrm{CO}_{2}$ emitter (Lahsen 2009). Carbon forestry science did not remain aloof of these political battles and competing scientific teams confirmed different scientific conclusions; scientists and politicians assembled the Amazon in two contrasting ways. Carbon markets could not escape these kinds of political-scientific constitutions.

Forests created further problems for carbon markets. One immediate challenge was that in the initial process for carbon credits, new forests would count as offsets because they provided "additionality", a key term that indicates the emissions reductions were additional beyond what was already planned in a business-as-usual scenario (Lohmann 2009); but preserving old forests would not. Additionality had an important role in policy terms as it attempted to prevent 
the cheating of the production of emissions credits (as it happened, there was some cheating with business-as-usual projections - see Lohmann 2009). In the case of forests, however, additionality meant that it was more economically effective to chop down old forests and then replant them than it was to preserve old forests as the former would attract carbon credits, but the latter would not. A market regulation to ensure the integrity of carbon trading ended up with unexpected consequences. The market had to be re-assembled to remove this flaw. International regulations were changed to enable the development of the United Nations Reducing Emissions from Deforestation and Forest Degradation Plus (or REDD+) program. This brought existing forests within the scope of the carbon markets, making credits possible for a previously insufficiently marketized externality. In consequence, the European argument regarding the Amazon as a carbon sink (Lahsen 2009) was now rather more politically useful in Brazil as it enabled the country to obtain significant funding, through carbon credits, for preserving the forests. Carbon markets were expanded internationally through economic and political reasoning. This had unintended consequences not least as these markets rubbed up against political-scientific constitutions about carbon science. These markets have been continually changing as external events or issues create challenges for the existing carbon market assemblage.

\section{CRISES AND THEIR RESPONSE: RE-ASSEMBLING CARBON MARKETS}

Challenges to the carbon market have also come from concerns about the economic that have been highlighted in a number of news articles. Major European energy companies, in particular, profited from carbon trading. For example, RWE settled a case brought by the German cartel office after having received a windfall of $€ 5$ bn from carbon credits between 2005 and 2007 (Kanter 2008). With such profitable opportunities came scandals and scams too. In 2014, the BBC reported on the case of Eco-Synergies Ltd, which was forcibly closed down by the British 
Insolvency Service. The company's purported goal was the provision of carbon credits, but it was so adept at selling these to investors that in court evidence it was revealed that EcoSynergies were making up to 869 percent profit on the credits (BBC 2014). The article further revealed that the credits were primarily "hot air" (with no concomitant emission reductions) and that 19 carbon credit firms had been shut down in the previous two years after ripping off investors to the tune of $£ 24 \mathrm{mn}$.

Such criticism has prompted significant effort to restore confidence in the markets. This has taken four primary forms: first, blame for scams being attributed to rogue traders or companies; second, blame for the failure of the markets being placed on government regulators; third, a claim that as the market is an experimentation in practice, it will deliver in the long-term even if it has failed in the short-term; fourth, a renewed attention to encouraging academic entrepreneurialism and expertise in companies trading in carbon credits. Carbon markets had to be re-assembled a little differently and while they may further embed core neoliberal ideas into the architecture of the market, they also open up the potential for a different kind of carbon market in the future. The carbon market, as assemblage, is inherently duplicitous in the sense that it holds the potential for more than one possible outcome or conclusion.

In the first case, the article referencing the example of Eco-Synergies Ltd chose to attach blame to the "callous" nature of the scam (BBC 2014), individualizing responsibility and diverting attention from potentially more systemic weaknesses of the design of carbon credits that enabled such a scam to be perpetrated. The German government's recovery of perceived excess profits from RWE likewise attributes blame to an energy cartel that would be halted in the interests of protecting consumers. Governments hoped that such action would encourage behavioral self-governance from companies. The core tenet that markets, themselves, could do 
no wrong was maintained with the deflection of attention to rogue individuals or companies (Lohmann 2011; Mirowski 2013).

Second, failures in carbon markets have been laid at the feet of government regulators for overallocating credits, allowing grandfathering (the free initial allocation of credits) or preventing a full trading to emerge through a sufficiently strong property rights regime. Indeed, this parallels debates about the US sulfur dioxide markets. While often considered a success story for marketized environmental solutions, legal challenges to the Environment Protection Agency mounted by states and utilities, as well as regulatory initiatives, prompted a collapse in credit prices after 2005 (Anderson and Libecap 2014). Market proponents like Anderson and Libecap (2014) argued that this was because of too much state interference resulting in an insecure property rights regime and pointed to the $\$ 3 \mathrm{bn}$ of stranded assets in emissions allowances that had simply been lost when the rules changed regarding the possibility of banking (storing) credits. Cap-and-trade markets are not meant to inspire too much regulation, but rather the reverse: markets are to be trusted to deliver on the solutions without too much governmental interference.

Third, with some careful scripting, carbon markets have been argued to have partially failed in the first instance but that this should not undermine the potential they have to succeed in the future. Yvo de Boer (then head of the UN Framework Convention on Climate Change) in acknowledging that the carbon markets were not watertight, advocated for their continual development (cited in Gregory 2008). Companies increasingly wanted to be part of the carbon market, attracted by the significant profit opportunities available. However, for market proponents, once captured in a regulatory framework that mandated reductions in caps, they would have to deliver on emissions reductions in the longer term (Kanter 2008, hints at this 
argument). Representatives of the same institutions that established markets in the first place have critiqued the current operation of these markets (describing the EU ETS for example as "learning by doing") and suggested that they need to be more fully marketized in the future this line of argument has been taken up for example by the EU Environment Commissioner Stavros Dimas (quoted in Kanter 2008). Sandor, himself, expressed confidence in the future of emissions markets to deliver reductions and, regardless, has affirmed that there is no alternative that could possibly be green and profitable (Lohmann 2011). As Lohmann puts it $(2012,102)$, placing Foucault's words in a different context: "the carbon market 'has always been offered as its own remedy",.

Fourth, given the potential crisis of legitimacy, carbon firms turned to academic expertise and support to justify their operations from the inside; indeed, some academics created their own companies to innovate and enhance the services offered to other carbon companies. As implied previously, carbon credits, particularly offsets, involve significant scientific expertise in assessing actual carbon absorption rates if they are not to be dismissed as "hot air". Enterprising scientists have aided the assembling of market-based policy prescriptions in practice. Climate scientists, wildlife biologists, foresters, GIS geographers and social scientists have joined the boards of or co-founded companies like TerraCarbon, ${ }^{\mathrm{v}}$ Jadora, CarbonTree, NatureBank, Offsetters and Rezatec. Rezatec, for instance, was formed in 2012 and attracted $£ 1 \mathrm{mn}$ of investment in 2016 to expand its big data analytics (Rezatec 2016a). Its business goals include taking satellite data and turning it into a series of land measurement and management techniques including measuring carbon fluxes in forests. As they put it on their webpage: "Rezatec is ideally placed to help organisations support carbon credit trading both for mandatory and voluntary carbon projects, including Reducing Emissions from Deforestation and Forest Degradation (REDD+) projects" (Rezatec 2016b). Enterprising scientists further 
legitimate carbon markets through their media and academic work, with, for example, James Tansey (STS scholar from the Sauber School of Business at UBC and CEO of NatureBank and co-founder and CEO of Offsetters) making clear that academics should make a difference through fostering business interventions and relationships (Hyslop 2016). Likewise Mark Maslin (co-founder of Rezatec) has stated that there are "win-win" solutions to climate change, not least among them that forestry policies should "provide livelihoods for local people through carbon credits" (Maslin and Austin, 2012, 184). ${ }^{\text {vi }}$ While this does not remove criticisms of carbon credits in terms of land grabs that have dispossessed people from their land (see Lohmann 2006), these claims do help establish the credibility of carbon markets. Equally, this academic entrepreneurialism shapes the kinds of carbon market activities that are deemed acceptable and appropriate, re-aligning market activities in ways concordant with climate science. In other words, while carbon science is being enrolled into marketization, it also creates the potential for a more determined response to climate crisis.

Carbon markets in practice have had to withstand some significant criticism about their performance. These criticisms, ranging from economic greed to concern about whether offsets really deliver carbon sinks, are significant challenges for carbon markets. They open up the prospect of a crisis generated from within the market. For economic critics of cap-and-trade markets, these examples provide prime evidence for why government interference makes these improper markets; likewise, for environmentalist critics, these scandals re-enforce suspicions that carbon markets are more about profit than environmental solutions. The result is a carbon market that is neither purely about climate change, neoliberalism, political regulation or profitability. There is fundamentally an informal compromise, which at various times erupts as one argument appears to gain in salience in response to an event or crisis within or beyond the 
market. Market regulations are then shuffled around and re-figured to protect and stabilize market operations. The assemblage becomes provisionally fixed again.

\section{CONCLUSION}

In this chapter I have explored how carbon markets are assembled as a response to climate change and are inspired by the aspiration for market-based solutions to environmental problems. These cap-and-trade markets are legitimated through the work of economists, policy practitioners and scientists, some of whom are directly connected to neoliberal think tanks. This is captured in some of the language of carbon markets, including the need for marketization to remove externalities, the primacy given to property rights for carbon, and a general ideal that the market knows best. Carbon markets demonstrate how neoliberalism is reassembled in the face of a climate crisis. This is not a smooth pathway as carbon markets require significant work to maintain the economic, environmental and political expectations vested within them. They have also become an end in themselves, much like the case of the green economy (more broadly) which is not merely about solving environmental issues, but is becoming a self-generating and self-fulfilling economy that relies on expectations of environmental crisis to continue to generate and maintain its own viability (Funk 2014; Jankovic and Bowman 2013).

Conceptually, the case of carbon markets hints at the possible contribution assemblage thinking might make to understanding and interpreting these as experiments in neoliberal innovation. A structural analysis that decries carbon markets as simply a neoliberal medium-term fix could find some justification in what has been presented in this chapter. Not least, the ideal of the market as the best information processor provides an epistemological warrant to ensuring that the climate crisis is neutralized through marketization. Other evidence for such a position 
includes the large profits being accrued with blame only being attributed to individual companies/traders that happen to be caught out and the argument that markets have failed because of too much regulation. These all resonate with a project of deepening and protecting neoliberalism in the face of crisis (Klein 2008; Mirowski 2013). The weakness of such an analysis is that it tells us rather less about the changing experimental practices of carbon markets in which political and environmental goals provide numerous checks on the system.

Understanding how carbon markets have emerged and become stabilized has been a core task for scholars inspired by actor-network theory. These approaches have provided a lively analysis of the kinds of calculative devices, equations and market architecture that have enabled carbon markets to attain a central position in climate policy (Callon 2009; MacKenzie 2009). The challenge with such a conceptualization, however, is that carbon markets appear too stable. The internal crises, the external influence from macro-political actors (whether the case of the EU, US, or Brazil), the changing regulations and rules, all hint that carbon markets are not fully settled. There is a significant potential for (fears of) events outside the network to shape these markets.

Assemblage thinking offers the potential for thinking about how these temporalities and spatialities come together (Anderson and McFarlane 2011); in other words, understanding how carbon markets are re-assembled in particular forms at particular moments in response to frictions from both within and outside the existing assemblage. An assemblage can also provisionally hold together (and be held together by) many different actors with different goals and aspirations, at least until a crisis prompts an irruption of the overflows that had not been fully settled or cooled down. If the climate crisis prompted a reaction from neoliberal thinkers to ensure that any climate policy response would be assembled in ways somewhat consistent 
with neoliberal ideals, then equally environmentalists have been concerned that the climate policy response is consistent with environmental goals. Within carbon markets then is the possibility to further embed neoliberal values, changed and translated as they are through the experience of carbon trading in practice, and the possibility to reject or disrupt neoliberal values. Not least, accepting cap-and-trade markets has meant accepting that states need to intervene to create markets to deal with externalities, a position that sits somewhat uncomfortably with the assertion that markets know best. Even further, should carbon markets fail, a carbon tax or further state intervention may well be the alternative option. Making the climate crisis safe for the neoliberal thought collective has meant some re-crafting of neoliberal ideals. In the process, interventions like carbon markets have exposed risks to untrammeled neoliberal ideals. These are the politically productive opportunities to stake claims for and shape the future differently.

\section{REFERENCES}

Anderson, Ben, Kearnes, Matthew, McFarlane, Colin and Swanton, Dan 2012. "On assemblages and geography." Dialogues in Human Geography 2(2): 171-189.

Anderson, Ben and McFarlane, Colin 2011. "Assemblage and geography." Area 43(2): 124127.

BBC 2014. "“Callous' firms in carbon credit scam shutdown." $B B C$ News, Available at: http://www.bbc.co.uk/news/business-27530039 (Last accessed 22/05/14).

Blok, Anders 2011. "Clash of the eco-sciences: Carbon marketization, environmental NGOs and performativity as politics." Economy and Society 40(3): 451-476.

Callon, Michel 2009. "Civilizing markets: Carbon trading between in vitro and in vivo experiments." Accounting, Organizations and Society 34(3/4): 535-548. 
Cameron, James 2007. "Richard Sandor." Time Magazine, Available at: http://content.time.com/time/specials/2007/article/0,28804,1663317_1663322_1669930 ,00.html (Last accessed 30/04/16)

Damro, Chad and Mendez, Pilar Luarces 2003. "Emissions trading at Kyoto: From EU resistance to union innovation." Environmental Politics, 12(2): 71-94.

Funk, MacKenzie 2014. Windfall: The Booming Business of Global Warming, New York: Penguin.

Gregory, Mark 2008. "The great carbon bazaar." $B B C$ News, Available at: http://news.bbc.co.uk/go/pr/fr/-/1/hi/business/7436263.stm (Last accessed 04/06/08).

Grubb, Michael 1992. "Memorandum.” In: HMSO Carbon/Energy Tax: Select Committee on the European Communities, London: HMSO, 11-12.

HMSO 1992. Carbon/Energy Tax: Select Committee on the European Communities, London: HMSO.

Howe, Joshua P. 2014. Behind the Curve: Science and the Politics of Global Warming, Seattle, WA: University of Washington Press.

Hyslop, Lucy 2016. "Lunch with Sauder School of Business professor James Tansey.” BC Business, Available: http://www.bcbusiness.ca/people/lunch-with-sauder-school-ofbusiness-professor-james-tansey (Last accessed 30/04/16).

Jankovic, Vladimir and Bowman, Andrew 2013. "After the green gold rush: The construction of climate change as a market transition." Economy and Society, 43(2): 233-259.

Kanter, James 2008. "EU carbon trading system brings windfalls for some, with little benefit to climate." International Herald Tribune, Available at: http://www.iht.com/articles/2008/12/09/business/windfall.php (Last accessed 12/12/08) Klein, Naomi 2008. The Shock Doctrine: The Rise of Disaster Capitalism, New York: Penguin. Klein, Naomi 2014. This Changes Everything: Capitalism vs. the Climate, London: Allen Lane. 
Lahsen, Myanna 2009. “A science-policy interface in the global south: the politics of carbon sinks and science in Brazil." Climatic Change, 97: 339-372.

Larner, Wendy 2011. "C-change? Geographies of crisis.” Dialogues in Human Geography, 1(3): 319-335.

Lohmann, Larry (ed) 2006 Carbon Trading: A Critical Conversation on Climate Change, Privatisation, and Power, Development Dialogue 48, Uppsala: Dag Hammarskjøld Centre.

Lohmann, Larry 2009. "Toward a different debate in environmental accounting: The cases of carbon and cost-benefit" Accounting, Organizations and Society 34(3/4): 499-534.

Lohmann, Larry 2011. "The endless algebra of carbon markets.” Capitalism Nature Socialism, 22(4): 93-116.

Lohmann, Larry 2012. "Financialization, commodification and carbon: The contradictions of neoliberal climate policy." Socialist Register, 48: 85-107.

MacKenzie, Donald 2009. "Making things the same: Gases, emission rights and the politics of carbon markets." Accounting, Organizations and Society, 34(3/4): 440-455.

Maslin, Mark 2014. "Neoliberal nightmare." Geographical Magazine, Available from: http://geographical.co.uk/opinion/item/490-neoliberal-nightmare (Last accessed 23/04/16).

Maslin, Mark and Austin, Patrick 2012. “Climate models at their limit?” Nature, 486: 183-184.

Meadows, Donella H., Meadows, Dennis L., Randers, Jørgen, and Behrens III, William W. 1972. The Limits to Growth: A Report for the Club of Rome's Project on the Predicament of Mankind, New York, NY: Signet.

Mirowski, Philip 2009. “Postscript.” In: Mirowski, Philip and Plehwe, Dieter (eds) The Road from Mont Pèlerin: The Making of the Neoliberal Thought Collective, Cambridge MA: Harvard University Press, 417-455. 
Mirowski, Philip 2013. Never Let a Serious Crisis go to Waste: How Neoliberalism Survived the Financial Meltdown, London: Verso.

Mirowski, Philip and Plehwe, Dieter (eds) 2009. The Road from Mont Pèlerin: The Making of the Neoliberal Thought Collective, Cambridge MA: Harvard University Press.

Mitchell, Timothy 2002. Rule of Experts: Egypt, Techno-politics, Modernity, Berkeley, CA: University of California Press.

Mol, Arthur P.J. and Spaargaren, Gert 2000. "Ecological modernisation theory in debate: a review." Environmental Politics 9(1): 17-49.

Müller, Martin and Schurr, Carolin 2016. "Assemblage thinking and actor-network theory: Conjunctions, disjunctions, cross-fertilisations." Transactions of the Institute of British Geographers 41(3): 217-229.

Oreskes, Naomi and Conway, Erik 2010. Merchants of Doubt: How a Handful of Scientists Obscured the Truth on Issues from Tobacco Smoke to Global Warming, New York: Bloomsbury Press.

Plehwe, Dieter and Walpen, Bernhard 2006. "Between network and complex organisation: The making of neoliberal knowledge and hegemony.” In: Plehwe, Dieter, Walpen, Bernhard and Neunhöffer, Gisela (eds) Neoliberal Hegemony: A Global Critique, London: Routledge, 27-50.

Rezatec, 2016a. "Rezatec announces $£ 1 \mathrm{~m}+$ seed funding round to deliver satellite data analytics to customers worldwide", http://www.rezatec.com/rezatec-announces-1mseed-funding.html (Last accessed 26-05-2016)

Rezatec, 2016b. “Carbon”, http://www.rezatec.com/carbon.html (Last accessed: 23-04-2016).

Sandor, Richard L. 1992. "Implementation issues: Market architecture and the tradeable instrument (in search of trees).” In: United Nations Combating Global Warming: Study 
on a Global System of Tradeable Carbon Emission Entitlements, New York, NY: United

Nations, 151-164.

Stern, Nicholas 2006. The Economics of Climate Change, Cambridge: Cambridge University Press.

United Nations, 1992. Combating Global Warming: Study on a Global System of Tradeable Carbon Emission Entitlements, New York, NY: United Nations.

\section{ENDNOTES}

i The term climate crisis is used throughout this chapter to indicate claims made by some environmentalists, scientists and others, in the media, political documents, academic literature and reports, that environmental issues have the power to overwhelm contemporary capitalist society. This does not imply there is a singular ontological climate crisis; such a statement is arguably inaccurate given the ways climate change circulates as policy problems (Randalls 2016). Rather, "climate crisis" is produced through events such as floods or heatwaves that become demonstrations of a changing climate, or political or economic meetings or reports that argue for a new political or economic reasoning generated through, for and sometimes to forestall the climate crisis.

ii The chapter is based on an uncatalogued collection of climate policy reports published by NGOs, HMSO, think tanks and other organizations (c.1980s-2000s) donated from the ENDS library and stored at University College London, and the collation of climate finance related online articles that I have collated over the past ten years.

iii The market for potent hydrofluorocarbons is the best known example with Klein $(2014,220)$ citing one Indian company as receiving $93.4 \%$ of its revenue from carbon credits traded from removing the pollution by-product of its other production process.

iv Personal communication from an architect of the E.U.'s carbon market (22/03/2011)

v TerraCarbon's head is Scott Settelmeyer, previously Chief Financial Officer at Chicago Climate Exchange.

vi Though note that Maslin (2014) has more recently argued that the redistribution of the Earth's resources in a fairer way would fundamentally contradict with neoliberalism and that is why geography's conscience (broadly conceived) is so troublesome for neoliberals. 